\title{
Generalized Edema, CTCAE
}

National Cancer Institute

\section{Source}

National Cancer Institute. Generalized Edema, CTCAE. NCI Thesaurus. Code C143202.

A disorder characterized by fluid accumulation in the tissues of the body including the skin. 